\title{
Variaton of Industrial Type Contributions on Working Performance
}

\author{
Ratna Balqis Nasution \\ UniversitasHarapan \\ Medan, Indonesia \\ nasutionratnabalqis@yahoo.com \\ Erlina \\ Universitas Sumatera Utara \\ Medan, Indonesi \\ erlina@usu.ac.id
}

\author{
Iskandar Muda \\ Universitas Sumatera Utara \\ Medan, Indonesia \\ iskandar1@usu.ac.id \\ Hasan Sakti Siregar \\ Universitas Sumatera Utara \\ Medan, Indonesia \\ hasan@usu.ac.id
}

\author{
Setareh Katircioglu \\ University of Kyrenia \\ North Cyprus, Via Mersin 10, Turkey \\ setareh.sodeyfi@gmail.com
}

\begin{abstract}
The purpose of this research is to see the influence of variation and types of large and medium industries in North Sumatera on the Absorption of the Labor force in North Sumatera Province. The type of research is descriptive quantitative. The data used are secondary data sourced from Statistics Agency of North Sumatera Province. The types of industries used as observation include Manufacture of Chemicals, Petroleum, Coal,_Rubber and Plastics, Manufacture of Fabricated_Metal Products, Machinery and Equipment, Manufacture of Food, Beverages and Tobacco, Manufacture of Wood, Including Furniture and Other Manufacturing Industries have an impact on the absorption of labor. Partially, the type of industries used as observation includes Manufacture of Fabricated_Metal Products and Manufacture of Wood are significant variables in the absorption of labor. The implication of this research is to know the types of large and medium industries that give contribution of job field so that the government of North Sumatera Province and Regency of City can arrange the right budget policy program so that more effective invite investor entry to North Sumatera.
\end{abstract}

Keywords-employment absorption; large industry; medium industry; local government; industrial stimulus

\section{INTRODUCTION}

The industrial process is a sector that has a major contribution. Along with the rapid development of industrialization and supported by the government's policy in facilitating the entry of foreign capital into Indonesia, this manufacturing sector has increased. An industrialization strategy that relies heavily on capital accumulation and High technology has led to polarization and dualism in the process development [1]. The facts show that the modern manufacturing sector lives alongside the traditional and less productive agricultural sector. North Sumatra Province based on cluster of BPS has various types of industries. The existing industrial types include industries used as observation include Manufacture of Chemicals, Petroleum, Coal, Rubber and Plastics, Manufacture of Fabricated_Metal Products, Machinery and Equipment, Manufacture of Food, Beverages and Tobacco, Manufacture of Wood, Including Furniture and Other Manufacturing Industries. Is it able to absorb the workforce?

\section{METHOD}

This study uses secondary data. The data were obtained from Central Bureau of Statistics. North Sumatera In Figures in the period 2000-2015. The types of industries used as observation include Manufacture of Chemicals, Petroleum, Coal,_Rubber and Plastics, Manufacture of Fabricated_Metal Products, Machinery and Equipment, Manufacture of Food, Beverages and Tobacco, Manufacture of Wood, Including Furniture and Other Manufacturing Industries [6]. The hypothesis was tested by using Structural Equation Modeling 
(SEM) with SMART PLS software. The data analysis technique in this research employed Structural Equation Modeling (SEM). SEM is a set of statistical techniques allowing testing of a series of relationships simultaneously. Furthermore, in the data processing, the writer used the aid from software SMART-PLS Structural Equation Modeling, which was one of the multivariate analyses capable of analyzing the variable relationships in complex manner [21], [22], [24] \& [30]. The hypotheses were tested using Structural Equation Modeling (SEM) with Smart-PLS software tools. The equation is formed as follows:

$$
Y_{2}=\alpha+b_{1} X_{1}+b_{2} X_{2}+b_{3} X_{3}+b_{4} X_{4}+b_{5} X_{5}+e
$$

$$
\begin{aligned}
\mathrm{X}_{1} & =\begin{array}{l}
\text { Manufacture of Chemicals, Petroleum, } \\
\end{array} \\
& \text { Coal,_Rubber and Plastics } \\
\mathrm{X}_{2} & \text { Manufacture of Fabricated_Metal Products, } \\
& \text { Machinery and Equipment } \\
\mathrm{X}_{3} & \text { Manufacture of Food, Beverages and }
\end{aligned}
$$

Tobacco

$\mathrm{X}_{4} \quad=$ Manufacture of Wood, Including

Furniture

$\mathrm{X}_{5}$

Y

$$
\begin{array}{ll}
\mathrm{b}_{1} \ldots \mathrm{b}_{5} & =\text { Coefficient } \\
\alpha & =\text { Constant } \\
\mathrm{e} & =\text { Error }
\end{array}
$$

This phase is done to test the suitability of the model to evaluate the goodness-of-fit index. Analysis using SEM requires some suitability index to measure the correctness of data and models.

\section{RESULT AND DISCUSSION}

A. Result

1) Evaluation of Structural Model (Inner Model) Inner model evaluation through the bootstrapping menu also generates $\mathrm{T}$-statistics values that will be used to test the hypothesis. The criteria are $\mathrm{T}$-statistic $>1.66$ [19] \& [23]. If the value of $\mathrm{t}$ count $<\mathrm{t}$ table then Ho accepted and when the value of $t_{\text {count }}>t$ table then Ho is rejected which means that the variable in question there is influence which is significant [25], [26] \& [35]. This means that the independent variables tested have an effect significantly to the dependent variable. The result of T-statistics value in the table path coefficients is presented in the following figure:

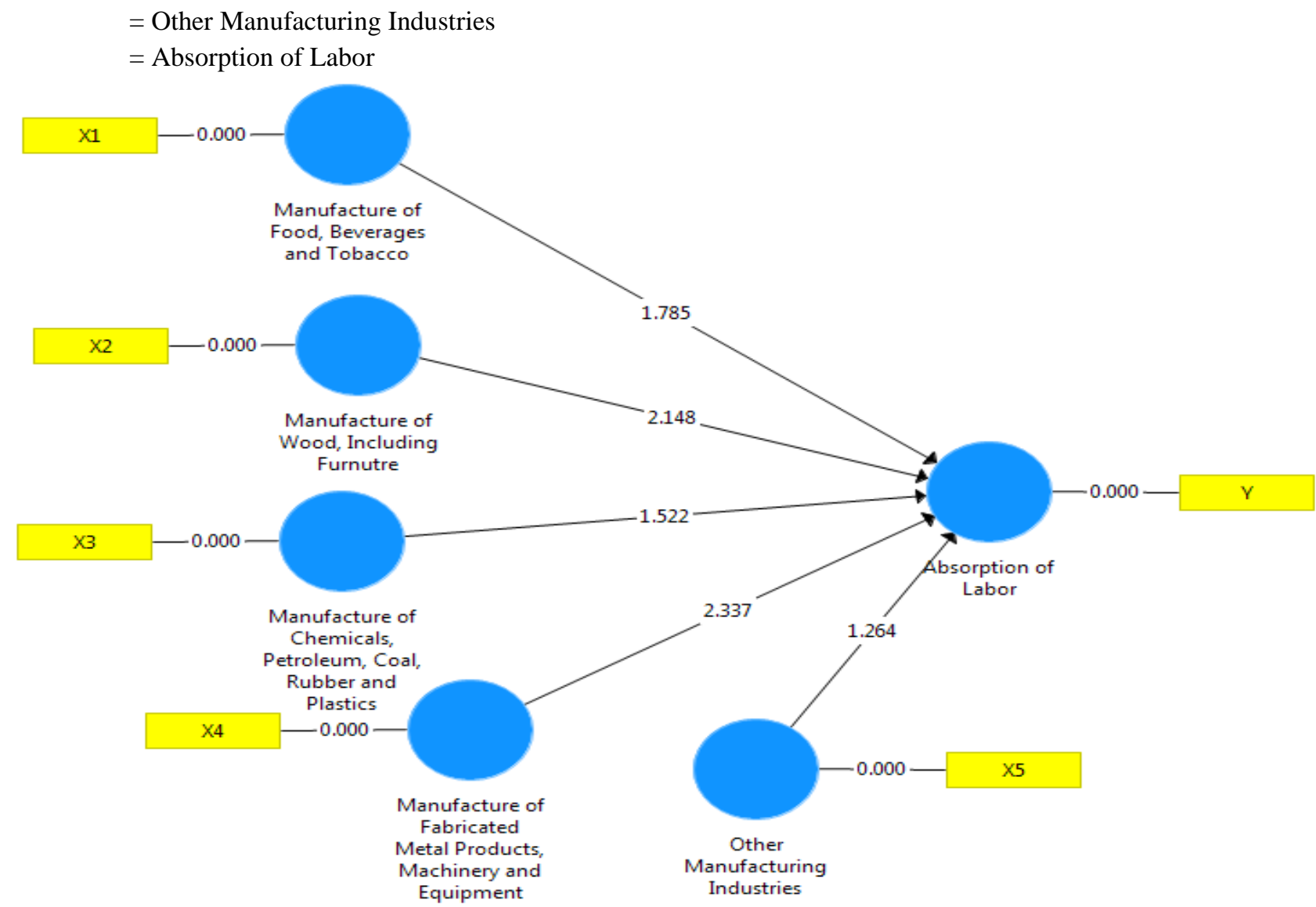

Figure 1. Overall Model with Coefficient 
The effect test can be seen in the following Table:

Table 1. The result of Bootsraping

\begin{tabular}{lccccc}
\multicolumn{7}{c}{ Table 1. The result of Bootsraping } \\
\hline & $\begin{array}{c}\text { Original } \\
\text { Sample } \\
(\mathrm{O})\end{array}$ & $\begin{array}{c}\text { Sample } \\
\text { Mean } \\
(\mathrm{M})\end{array}$ & $\begin{array}{c}\text { Standard } \\
\text { Deviation } \\
(\text { STDEV })\end{array}$ & T Statistics & $\begin{array}{c}\text { P } \\
\text { Values }\end{array}$ \\
\hline $\begin{array}{l}\text { Manufacture of Chemicals, Petroleum, } \\
\text { Coal,_Rubber and Plastics -> Absorption of Labor }\end{array}$ & 0,398 & 0,407 & 0,262 & 1,522 & 0,129 \\
\hline $\begin{array}{l}\text { Manufacture of Fabricated_Metal Products, } \\
\text { Machinery and Equipment -> Absorption of Labor }\end{array}$ & $-1,472$ & $-1,365$ & 0,630 & 2,337 & 0,020 \\
\hline $\begin{array}{l}\text { Manufacture of Food, Beverages and Tobacco -> } \\
\text { Absorption of Labor }\end{array}$ & $-0,783$ & $-0,700$ & 0,438 & 1,785 & 0,075 \\
\hline $\begin{array}{l}\text { Manufacture of Wood, Including Furnutre -> } \\
\text { Absorption of Labor }\end{array}$ & 1,089 & 1,122 & 0,507 & 2,148 & 0,032 \\
\hline $\begin{array}{l}\text { Other Manufacturing Industries -> Absorption of } \\
\text { Labor }\end{array}$ & $-0,709$ & $-0,639$ & 0,561 & 1,264 & 0,207 \\
\hline & & & Source: PLS Output & $(2017)$
\end{tabular}

Based on the above table produces coefficient of 0.005 , smaller than $1.66(\alpha=5 \%)$ then the decision of hypothesis testing reject $\mathrm{HO}$ and accept the hypothesis Ha [3], [7], [11], [12] \& [13]. The results show that the variables of the type of industries used as observation include Manufacture of Fabricated_Metal Products and Manufacture of Wood are significant variables in the absorption of labor. In addition to hypothesis testing through the bootstrapping menu that produces T-statistics, inner model evaluation is also done by reviewing the R-Square value [8], [9], [10], [15], [16] \& [17]. The R-square value generated from the inner model evaluation is presented in the following table:

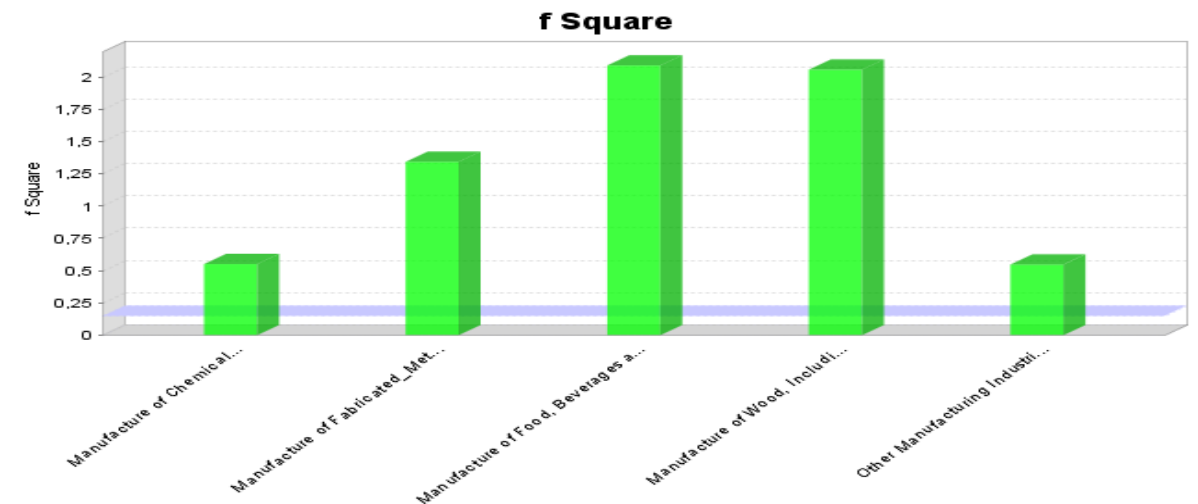

Figure 2. F Square

Source: PLS Output, (2017)

Table 2. R-Square Value

\begin{tabular}{lccccc}
\hline & $\begin{array}{c}\text { Original } \\
\text { Sample (O) }\end{array}$ & $\begin{array}{c}\text { Sample } \\
\text { Mean (M) }\end{array}$ & $\begin{array}{c}\text { Standard } \\
\text { Deviation } \\
(\text { STDEV) }\end{array}$ & $\begin{array}{c}\text { T Statistics } \\
(|\mathrm{O} / \mathrm{STDEV}|)\end{array}$ & P Values \\
\hline $\begin{array}{l}\text { Absorption of } \\
\text { Labor }\end{array}$ & 0,701 & 0,799 & 0,114 & 6,132 & 0,000
\end{tabular}

The variation of R-Square value of $70.1 \%$. The existence of small industries also has a great contribution on economic development of a region, because with the number of business units that many will create jobs and be able to absorb labor so it has the potential to reduce unemployment in an area [2],[4],[5],[20]\&[22]. Types of wood industry, wooden goods and other processing industries have enough influence on the industry in Indonesia. This shows that wood industry, wooden goods, furniture, recycling, goods wicker and other processing industries are quite potential in reducing
Source: PLS Output. (2017)

unemployment because it absorbs a relatively large workforce [31], [32], [33] \& [34]. One of indicator to see how large an area is absorbing energy work is by looking at some variables that affect demand labor in a company [28]. Small industry development is the way that is considered a major role in the development of the manufacturing industry [18]\&[29]. The development of small industries will help overcome unemployment problems considering the technology used is labor-intensive technology so it can increase employment and business opportunities, which in turn encouraging regional 
development and rural areas [14]\&[27]. The role of the home industry or small industry has an influence big on the economy in Indonesia due to build an industry this small does not require a large capital and able to absorb labor.

\section{CONCLUSIONS}

The results indicate the existence of large and medium industries that stood in North Sumatra Province have not impact on the absorption of the number of workers. Partially the type of industries used as observation includes Manufacture of Fabricated_Metal Products and Manufacture of Wood are significant variables on the absorption of labor. The implications of this research with the existence of large and medium industry then North Sumatra provincial government should increase the allocation of local government expenditure funds to stimulate the entry of investors to North Sumatra so it can absorb labor in the City/District/Regency.

\section{REFERENCES}

[1]. Avolio, B. J., Waldman, D. A., \& McDaniel, M. A. "Age and work performance in nonmanagerial jobs: The effects of experience and occupational type". Academy of Management Journal, 33(2), (1990). pp.407-422.

[2]. Aycan, Z. "Cross-cultural industrial and organizational psychology: Contributions, past developments, and future directions". Journal of Cross-Cultural Psychology,31(1), (2000).pp.110-128.

[3]. Azlina, Nur. Amir Hasan, Desmiyawati\&Muda, I. "The Effectiveness of Village Fund Management (Case Study at Villages in Coastal Areas in Riau)". International Journal of Economic Research. Vol. 14 Issue 12. (2017). pp.325-336.

[4]. Behrman, D. N., \& Perreault, W. D. "Measuring the performance of industrial salespersons". Journal of Business Research, 10(3), (1982). pp.355-370.

[5]. Brayfield, A. H., \& Crockett, W. H. "Employee attitudes and employee performance'. Psychological bulletin, 52, (1955).396.

[6]. Central Bureau of Statistics. North Sumatera In Figures 2016. Republic of Indonesia. Jakarta. (2016).

[7]. Dalimunthe, D.M.J.,Fadli, and Muda, I. "The application of performance measurement system model using Malcolm Baldrige Model (MBM) to support Civil State Apparatus Law (ASN) number 5 of 2014 in Indonesia". International Journal of Applied Business and Economic Research. Vol.14 Issue 11. (2016). pp.7397-7407.

[8]. Erlina, Ari Saputra \& Muda, I. "Antecedents of Budget Quality Empirical Evidence from Provincial Government In Indonesia". International Journal of Economic Research. Vol. 14 Issue 12. (2017). pp.301-312.

[9]. Erlina. Ari Saputra \& Muda, I. "The Analysis of the Influencing Factors of Budget Absorption".International Journal of Economic Research. Vol. 14 Issue 12. (2017). pp.287-300.

[10]. Erlina. "ConflictofInterestImpact: FactorsAnalysisAffectingtheBudgetQualityinMedanCity". International Journal of Economic Research.Vol.14 Issue 12. (2017). pp.135-145.

[11]. Gusnardi, Riadi, R.M., and Muda, I. "Competency mapping and analysis of students competency based on economics subject national examination and its alternative solutions in state high schools at Pekanbaru". International Journal of Economic Research. Vol.3 Issue 5. (2016). pp.2133-2148.

[12]. Handoko, ,Bagus. Sunaryo \&Muda, I. "Difference Analysis of Consumer Perception of Motorcycle Product Quality". International Journal of Economic Research. Vol. 14 Issue 12. (2017). pp.363-379.

[13]. Hasan, Amir, Gusnardi \&Muda, I.“Analysis of Taxpayers and Understanding Awareness Increase in Compliance with Taxpayers Individual Taxpayers". International Journal of Economic Research. Vol.14 Issue 12. (2017). pp. 75-90.

[14]. Haslam, S. A., \& Ellemers, N. "Social identity in industrial and organizational psychology: Concepts, controversies and contributions". International review of industrial and organizational psychology, 20(1), (2005). pp.39-118.

[15]. Lubis, A.,Torong, Z.B., and Muda, I. "The urgency of implementing balanced scorecard system on local government in North Sumatra - Indonesia". International Journal of Applied Business and Economic Research. Vol.14 Issue 11. (2016). pp.7575-7590.

[16]. Lubis, A.F., Lubis, T.A., and Muda, I. "The role of Enterprise Resource Plan (ERP) configuration to the timeliness of the financial statement presentation". International Journal of Applied Business and Economic Research. Vol.14 Issue 11. (2016). pp.7591-7608.

[17]. Lutfi, M.,Nazwar, C., and Muda, I "Effects of investment opportunity set, company size and real activity manipulation of issuers in Indonesia Stock Exchange on stock price in Indonesia”. International Journal of Economic Research. Vol.13 Issue 5. (2016). pp.2149-2161.

[18]. Mansfield, E., \& Lee, J. Y. "The modern university: contributor to industrial innovation and recipient of industrial R\&D support”. Research policy. 25(7), (1996). pp.1047-1058.

[19]. Muda, I and Abykusno Dharsuky. "Impact of Region Financial Information System (SIKD) Quality, Role Ambiguity And Training on Precision of Financial Statement of Local Government Presentation In North Sumatra". International Journal of Applied Business and Economic Research, Vol.13 Issue 6. (2015). pp.4283-4304.

[20]. Muda, I, Deni Yuwilia Wardani, Erlina, Azhar Maksum, Ade Fatma Lubis and Rina Bukit. "The Influence of Human Resources Competency and The Use of Information Technology on The Quality of Local Government Financial Report with Regional Accounting System as an Intervening". Journal of Theoretical and Applied Information Technology. Vol.95 Issue 17. (2017). pp.1432-1451.

[21]. Muda, I, Dharsuky. A., Siregar, H.S., and Sadalia, I. "combined loading and Cross-dimensional loadings timeliness of presentation of financial statements of local government". IOP Conference Series : Materials Science and Engineering. Bandung, (2017). 180. doi: 10.1088/1757-899X/180/1/012099.

[22]. Muda, I, Marlon Sihombing, Erni Jumilawati and Abikusno Dharsuky. "Critical Success Factors Downstream Palm Oil Based Small And Medium Enterprises (SME) In Indonesia". International Journal of Economic Research. Vol.13 Issue 8. (2016). pp. 3531-3538.

[23]. Muda, I., Rafiki, A., \& Harahap, M. R. "Factors Influencing Employees' Performance: A Study on the Islamic Banks in Indonesia". International Journal of Business and Social Science, Vol.5Issue 2. (2014). pp. 73-80.

[24]. Muda, I.,Dharsuky, A.,Sadalia, I., and Siregar, H.S. "Impact of capital investments and cash dividend policy on Regional Development Bank (BPD) PT. Bank Sumut to the district own source revenue and economic growth". International Journal of Applied Business and Economic Research. Vol.14 Issue 11. (2016). pp.7863-7880. 
[25]. Muda, Iskandar. "The Effect of Supervisory Board CrossMembership and Supervisory Board Members' Expertise to The Disclosure of Supervisory Board's Report : Empirical Evidence From Indonesia". European Research Studies Journal. Vol.XX Issue 3A. (2017). pp.702-716.

[26]. Nasir, Azwir. Yesi Mutia Basri, Kamaliah \&Muda, I. "Effectiveness of Potential Tax Region as the Real Local Revenue Sources in Riau Coastal Area". International Journal of Economic Research. Vol. 14 Issue 12. (2017). pp.313-324.

[27]. Oldham, G. R., \& Cummings, A. "Employee creativity: Personal and contextual factors at work". Academy of management journal, Vol.39 Issue 3.(1996). 607-634.

[28]. Oltra, V. "Environmental innovation and industrial dynamics: the contributions of evolutionary economics". Cahiers $d u$ GREThA, 28(27). (2008). 77-89.

[29]. Porter, M. E. "The contributions of industrial organization to strategic management". Academy of Management Review, 6(4).(1981). pp.609-620.

[30]. Sadalia, .Isfenti. Nur Ahmadi Bi Rahamani \&Muda, I. "The Significance of Internet Based Financial Information Disclosure on Corporates' Shares in Indonesia". International Journal of Economic Research. Vol. 14 Issue 12. (2017). pp.337-346.

[31]. Sewell, G. "The discipline of teams: The control of team-based industrial work through electronic and peer surveillance". Administrative science quarterly, (1998). pp.397428.

[32]. Stewart, G. L., \& Barrick, M. R. "Team structure and performance: Assessing the mediating role of intrateam process and the moderating role of task type". Academy of management Journal, Vol.43 Issue 2,(2000).pp.135-148.

[33]. Straus, S. G., \& McGrath, J. E. "Does the medium matter? The interaction of task type and technology on group performance and member reactions". Journal of applied psychology, 79(1), (1994). 87-104.

[34]. Waldman, D. A. "The contributions of total quality management to a theory of work performance". Academy of Management review, Vol. 19 Issue 3, (1994). pp.510-536

[35]. Yahya, Idhar., Torong, Z.B., and Muda, I.. :Influence Behavior in Legislature Budget Development of Regions in the Province of Aceh and North Sumatra". International Journal of Economic Research, Vol.14 Issue 8. (2017). pp. 147-159. 